\title{
Growth Characteristic of Fungus strain MGS-2 in a Defined Medium Containing Organic Acids Derived from Peat Soil
}

\author{
DIANA NURANI* AND KOESNANDAR
}

\author{
Laboratory of Industrial Technology Development for Agro and Biomedical \\ Center for Bioindustrial Technology, Agency for the Assessment and Application of Technology (BPPT) \\ BPPT Buiding II $15^{\text {th }}$ floor, Jalan MH Thamrin No 8, Jakarta 10340, Indonesia
}

\begin{abstract}
Some organic acids derived from lignin degradation in peat soil have significant role in lowering $\mathrm{pH}$ of peat soil and have phytotoxic effect for plant. A series of experiments has been conducted to decrease the amount of organic acids in peat soil by microbial treatment. The aim of the study was to characterize the growth of selected fungus using organic acids extracted from peat soil as a sole carbon source. The fungus strain MGS-2 was grown in a liquid medium containing various concentrations of organic acids extracted from peat soil, nitrogen and salt at initial $\mathrm{pH}$ of 3.8. The cell growth, $\mathrm{pH}$ of medium and the content of organic acids were analyzed. The identification of fungus MGS-2 was based on the $28 \mathrm{~S}$ rDNA. The ability of Hypocrea sp. MGS-2 to degrade toxic organic acid derived from peat soil has never been reported. The organic acid and nitrogen optimum for the growth were $33.1 \mathrm{mN}-\mathrm{NaOH}$ and $2 \mathrm{~g}\left(\mathrm{NH}_{4}\right)_{2} \mathrm{SO}_{4}$ per liter medium, respectively. The interaction between carbon and nitrogen source was found to be significantly influenced by the increment of $\mathrm{pH}$ medium, however this interaction did not effect to the cell growth and reduction of organic acids. The carbon source affected significantly to the cell growth and acid metabolism by fungus strain MGS-2 The fungus could not grow well in the medium without yeast exract, but grew well in the limitation of $\mathrm{NH}_{2} \mathrm{SO}_{4}$, suggested that yeast extract was metabolized as nitrogen source. The optimum degradation of organic acids extracted from peat soil by MGS-2 was obtained at $\mathrm{pH} 3.8$. These result suggested that the cell mass production of MGS-2 can be performed in optimal defined medium utilizing organic acid derived from peat soil. Molecular identification revealed that the MGS-2 was closed to Hypocrea sp.
\end{abstract}

Key words: acid tolerant-fungus, peat soil, organic acid degrading-fungus

Beberapa asam organik yang berasal dari degradasi lignin dalam tanah gambut memiliki peran penting dalam menurunkan $\mathrm{pH}$ tanah dan toksisitas terhadap tanaman. Serangkaian riset telah dilakukan untuk mengurangi jumlah asam organik dalam tanah gambut dengan perlakuan mikroba. Tujuan dari riset ini adalah untuk mengkarakterisasi pertumbuhan mikroba terpilih menggunakan asam organik yang diekstraksi diekstraksi dari tanah gambut sebagai sumber karbon tunggal. Strain jamur MGS-2 ditumbuhkan dalam medium cair yang mengandung berbagai konsentrasi asam organik, nitrogen dan garam pada $\mathrm{pH}$ awal 3,8. Pertumbuhan sel, $\mathrm{pH}$ dan kandungan asam organik dianalisis. Identifikasi jamur MGS-2 didasarkan pada 28S rDNA. Kemampuan Hypocrea sp.strain MGS-2 dalam menurunkan asam organik beracun yang berasal dalam tanah gambut belum pernah dilaporkan. Asam organik dan nitrogen yang optimal untuk pertumbuhan adalah 33,1 mN-NaOH dan $2 \mathrm{~g}$ $\left(\mathrm{NH}_{4}\right)_{2} \mathrm{SO}_{4}$ per liter media, masing-masing. Interaksi antara sumber karbon dan nitrogen berpengaruh terhadap peningkatan $\mathrm{pH}$, namun interaksi ini tidak berpengaruh terhadap pertumbuhan sel dan pengurangan asam organik. Sumber karbon terpengaruh secara nyata terhadap pertumbuhan sel dan metabolisme asam oleh strain MGS-2. Strain Hypocrea sp.MGS-2 tidak bisa tumbuh dengan baik di media tanpa ekstrak ragi, tetapi tumbuh baik dengan pemberian $\mathrm{NH}_{2} \mathrm{SO}_{4}$ secara terbatas. Degradasi optimum asam organik oleh strain Hypocrea sp.MGS-2 berlangsung pada $\mathrm{pH}$ awal $\mathrm{pH} 3,8$. Hasil ini menunjukkan bahwa produksi sel MGS-2 dapat dilakukan dengan medium minimal menggunakan asam organik dari tanah gambut. Identifikasi molekuler mengungkapkan bahwa MGS-2 adalah Hypocrea sp.

Kata kunci: asam organik, Hypocrea sp. strain MGS-2, jamur toleran asam, tanah gambut

Tropical peat consists of lignin, hemicellulose, cellulose, and protein. Lignin biodegradation in peat soil produces several organic acids. The organic acids resulted in lignin biodegradation process are from the groups of aliphatic and aromatic compounds. Aliphatic compounds found in peat soil are originated from carboxylic acid derivatives such as acetic, formic,

*Corresponding author; Phone/Fax: +62-21-3169513/+6221-3169510,Email: diana.nurani@yahoo.co.id propionic, and butyric acids, while the aromatic compounds are from phenolic acid derivatives such as vanillic, $p$-hydroxybenzoic, $p$-coumaric, ferulic, and syringic acids (Alexander 1977; Stevenson 1994; Hartley et al. 1984).

Phenolic acid generally has negative effects to plant nutrient absorption and growth (Tadano et al. 1992). Phenolic acid, with a range of concentration between 4-30 mM, showed toxic effects in several 
species of plant (Guenzi et al. 1966). Phenolic acids such as ferulic, $p$-coumaric, and $p$-hydroxybenzoic acids are considered more harmful compared to carboxylic acids, because of its greater toxicity. Other than harming plants, organic acid found in peat soil also causes low $\mathrm{pH}$.

Several microbes in soil have the ability to quickly decompose organic acids. Studies have been conducted to develop the utilization of organic acids as carbon source for microbes (McCarty et al. 1986). Phenolic acid, which was chosen as one of the organic acid that can be utilized by the microbes in soil and rhizosphere, has been studied by adding one type of phenolic acid with a concentration of $\geq 0,25 \mu \mathrm{mol} \mathrm{g}$ of soil. The addition of $p$-hydroxybenzoic acid in soil showed that microbes were able to utilize the acid as their single source of carbon (Mohamed et al.2009).

Several genera of bacteria are able to degrade phenolic acid and use it as a carbon source, one of them is Azotobacter (Juarez et al. 2005), while from the group of actinomycetes, Streptomyces sannanensis can grow optimally by using ferulic acid with a concentration of $5 \mathrm{mM}$ as its carbon source (Ghosh et al. 2007). Beside bacteria and actinomycetes, there are also several fungi that are able to utilize phenolic acid, such as the white rot fungus Schyzophyllum commune, Pycnoporus cinnabarinus, and Trametes sp., using coumaric and ferulic acids as their single carbon source (Sachan et al.2010). According to Ghosh et al. (2006), the fungi Paecilomyces variotii grows optimally by using ferulic acid as its carbon source with a concentration of $10 \mathrm{mM}$.

We have been conducting a series study to decrease the amount of phytotoxic organic acid in peat soil. The aim of the current study was to characterize the growth of selected fungus using organic acid extracted from peat soil as a sole carbon source.

\section{MATERIALS AND METHODS}

\section{Extraction of Organic Acid and Liquid} Medium. Organic acids were extracted from peat soil using a modified method from Maciak and Harms (1986). Ten grams of soil was added by $100 \mathrm{~mL}$ of $2 \mathrm{M}$ $\mathrm{NaOH}$ and then agitated on a shaker for $3 \mathrm{~h}$ at room temperature. The solution was separated from the solid fraction by centrifugation for $20 \mathrm{~min}$ at $8000 \mathrm{rpm}$ (8770 x g). $\mathrm{H}_{2} \mathrm{SO}_{4}$ solution was added gradually to the liquid fraction while being mixed, until precipitation was fully formed. Liquid fraction was separated by centrifugation for $20 \mathrm{~min}$ at $8770 \mathrm{x}$ g and then used as carbon source in this study.

Fungi and liquid medium. A medium containing organic acid at low $\mathrm{pH}$ (3.8) was used to isolate a potent fungal-degrading organic acid of peat soil. The growth characterization of MGS-2 was done using modified Czapek's media (Labeda, 1990), with the following composition $\left(\mathrm{g} \mathrm{L}^{-1}\right): 0.5 \mathrm{~g}$ of $\mathrm{MgSO}_{4} \cdot 7 \mathrm{H}_{2} \mathrm{O} ; 3 \mathrm{~g}$ of $\left(\mathrm{NH}_{4}\right)_{2} \mathrm{SO}_{4} ; 1 \mathrm{~g}$ of $\mathrm{KH}_{2} \mathrm{PO}_{4} ; 0.5 \mathrm{~g}$ of yeast extract; and $33.1 \mathrm{mN}-\mathrm{NaOH}$ organic acid, with the $\mathrm{pH}$ medium 3.8.

Analysis of Total Acid and Phenolic Acid. Total acid was quantified by titration method (AOAC, 19190). Two $\mathrm{mL}$ of sample was added to a $250 \mathrm{~mL}$ Erlenmeyer. The liquid was diluted with aquades until it reached $20 \mathrm{~mL}$ of volume (Dilution factor $=10$ ) and was added several drops of phenolphthalein indicator. The solution was titrated with $0.1 \mathrm{~N} \mathrm{NaOH}$ until a pink color was formed. The concentration of phenolic acid derivatives was detected by HPLC. Ten $\mathrm{mL}$ of sample or medium was acidified to $\mathrm{pH} 2.5$ with $1 \mathrm{M} \mathrm{HCl}$. The solution was then diluted by adding $10 \mathrm{~mL}$ of methanol $\left(\mathrm{CH}_{4} \mathrm{O}\right)$ : water $\left(\mathrm{H}_{2} \mathrm{O}\right)$ : acetic acid $\left(\mathrm{C}_{2} \mathrm{H}_{4} \mathrm{O}_{2}\right)$ solution. The solution was then used in HPLC to determine the phenolic acid concentration. The types of phenolic acid which constitute the sample was determined by partition separation system using a reversed-phase column (Bondapak C18 column, $3.9 \times 300 \mathrm{~mm}$ ) and a UV detector with D2 light at $240 \mathrm{~nm}$ wavelength.

Fungal Growth Characterization. Growth characterization was determined by optimizing carbon and nitrogen source. The concentrations of organic acid used as carbon source $(\mathrm{C} 1, \mathrm{C} 2, \mathrm{C} 3$, and $\mathrm{C} 4)$ are $33.1 ; 66.2 ; 99.3 ; 132.4 \mathrm{mN}-\mathrm{NaOH} \mathrm{L} \mathrm{L}^{-1}$ of medium, while the concentrations of $\left(\mathrm{NH}_{4}\right)_{2} \mathrm{SO}_{4}$ as nitrogen source $(\mathrm{N} 1, \mathrm{~N} 2, \mathrm{~N} 3, \mathrm{~N} 4)$ are 1, 2, 3, $4 \mathrm{~g} \mathrm{~L}^{-1}$ of medium. $10 \mathrm{~mL}$ of MGS-2 culture was inoculated into $100 \mathrm{~mL}$ medium (with composition as stated in Table 1) and incubated at room temperature for 48 hours with agitation at $120 \mathrm{rpm}$. Observation was conducted by measuring total acid, $\mathrm{pH}$, cell growth (dry cell mass). The study was done with two repetitions for each treatment.

28s rDNA-based Identification of MGS-2. The $28 \mathrm{~S}$ rDNA of the MGS-2 were amplified by PCR using a pair of specific primers, NL1(5'-GCATATCAATAAG CGGAGGAAAAG-3') and NL4 (5'-GGTCCGTGTTT CAAGACGG-3') (Park et al. 2002). The PCR product was analyzed using 1\% agarose gel electrophoresis. After the DNA band was confirmed, to obtain nucleotide sequences of 28s rDNA gene, the PCR product was purified and directly sequenced using both primers by an automated DNA sequencer 
Table 1 Carbon source and nitrogen source variation in growth medium

\begin{tabular}{|c|c|c|c|c|}
\hline \multirow{2}{*}{$\begin{array}{l}\text { Carbon Source }=\text { organic acid } \\
\left(\mathrm{mN}-\mathrm{NaOH} \mathrm{L} \text { L }^{-1} \text { medium }\right)\end{array}$} & \multicolumn{4}{|c|}{ Nitrogen Source $=\left(\mathrm{NH}_{4}\right)_{2} \mathrm{SO}_{4}\left(\mathrm{~g} \mathrm{~L}^{-1}\right.$ medium $)$} \\
\hline & $\mathrm{N} 1=1$ & $\mathrm{~N} 2=2$ & $\mathrm{~N} 3=3$ & $\mathrm{~N} 4=4$ \\
\hline $\mathrm{C} 1=33.1$ & $\mathrm{C} 1 \mathrm{~N} 1$ & $\mathrm{C} 1 \mathrm{~N} 2$ & $\mathrm{C} 1 \mathrm{~N} 3$ & $\mathrm{C} 1 \mathrm{~N} 4$ \\
\hline $\mathrm{C} 2=66.2$ & $\mathrm{C} 2 \mathrm{~N} 1$ & $\mathrm{C} 2 \mathrm{~N} 2$ & $\mathrm{C} 2 \mathrm{~N} 3$ & $\mathrm{C} 2 \mathrm{~N} 4$ \\
\hline $\mathrm{C} 3=99.3$ & $\mathrm{C} 3 \mathrm{~N} 1$ & $\mathrm{C} 3 \mathrm{~N} 2$ & $\mathrm{C} 3 \mathrm{~N} 3$ & $\mathrm{C} 3 \mathrm{~N} 4$ \\
\hline $\mathrm{C} 4=132.4$ & C4N1 & C4N2 & $\mathrm{C} 4 \mathrm{~N} 3$ & $\mathrm{C} 4 \mathrm{~N}^{2}$ \\
\hline
\end{tabular}

*) Other compositions of the growth media include MgSO4.7H2O; KH2PO4 and yeast extract.

(Applied Biosystem 3130). The sequences were then analyzed for identity using NCBI BLAST (http://www.ncbi.nlm.nih.gov) with 28s rDNA sequences available at the NCBI database. Multiple sequence alignment of MGS-2 sequence and its BLAST result sequences was carried out using Clustal $X$ software (http://www.clustal.org/clusta12/). Phylogenetic tree was then constructed by distance method in PHYLIP software (http://evolution.genetics. washington.edu/phylip.html).

Statistical Analysis. Data resulted from this study was analyzed as a factorial experiment with completely randomized design (2 factors). Every treatment was repeated two times. Significant difference between treatments was carried out by Duncan analysis.

\section{RESULTS}

Growth Characterization of MGS-2. MGS-2 reached its optimum growth when cultured in media with a concentration of organic acid of $33.1 \mathrm{mN}$ $\mathrm{NaOH}$, and a concentration of nitrogen source of $2 \mathrm{~g} \mathrm{~L}^{-1}$. The $\mathrm{pH}$ of the medium increased to 5.43 at optimum growth (Table 2, Fig 1), followed by a decrease in organic acid as much as $4.8 \mathrm{mN}-\mathrm{NaOH}$ during 48 hours of fermentation (Fig 2).

The results of variety analysis towards $\mathrm{pH}$ showed that the interaction of $\mathrm{C}$ and $\mathrm{N}$ significantly influenced the $\mathrm{pH}$ at $5 \%$ level $(\mathrm{p}<0.05 \rightarrow 0.00<0.05)$. This result suggested that the $\mathrm{C}$ and $\mathrm{N}$ source was strongly needed by strain MGS-2 in degrading organic acid. The Duncan test also indicated that the combination factor of C1N2 (33.1 mN-NaOH of carbon source and $2 \mathrm{~g} \mathrm{~L}^{-1}$ of nitrogen source) significantly produced a different $\mathrm{pH}$ compared to other combination factors of treatment.

The results of variety analysis towards cell growth showed that interaction of $\mathrm{C}$ and $\mathrm{N}$ did not significantly affects the cell growth at $5 \%$ level $(\mathrm{p}<0.05 \rightarrow 0.00<$ 0.05 ). A single factor analysis showed that only $\mathrm{C}$ factor significantly influenced the cell growth at $5 \%$ level $(\mathrm{p}<0.05 \rightarrow 0.00<0.05)$. The Duncan test towards the $\mathrm{C}$ factor also showed that there were two treatment groups produced a significant influence to the cell growth. The Duncan test also indicated that carbon source was strongly required for the growth of strain MGS-2.

In total acid analysis, the interaction of $\mathrm{C}$ and $\mathrm{N}$ did not affects the total acid reduction at $5 \%$ level $(\mathrm{p}<0.05$ $\rightarrow 0.00<0.05$ ). However, in a single factor analysis, $\mathrm{C}$ factor significantly influenced the total acid reduction at $5 \%$ level $(\mathrm{p}<0.05 \rightarrow 0.00<0.05)$, and the $\mathrm{N}$ factor also significantly influenced the total acid reduction at $5 \%$ level $(\mathrm{p}<0.05 \rightarrow 0.00<0.05)$. The Duncan test towards the $\mathrm{C}$ factor showed that two groups of treatment exhibited different effects to the cell growth. The Duncan test towards the $\mathrm{N}$ factor also showed a similar result to the cell growth. The analysis of variance and Duncan test indicated that each carbon and nitrogen source is strongly required by strain MGS-2 during degradation of organic acid.

Optimization of Nitrogen. Strain MGS-2 was unable to grow in medium without yeast extract. In this medium, the $\mathrm{pH}$ increase to 4.39 at $36 \mathrm{~h}$ incubation. In medium without ammonium sulphate, the strain MGS2 was still capable to grow, and the $\mathrm{pH}$ medium was found increasing to 5.79 at $36 \mathrm{~h}$ incubation (Fig 4).

Optimization of pH. Effect of initial $\mathrm{pH}$ value on strain MGS-2 growth was investigated by treatment of initial $\mathrm{pH}$ variation in medium with optimum $\mathrm{C}$ and $\mathrm{N}$ concentration range from 3.8-6.5. The result showed higher initial $\mathrm{pH}$ gave slower rate of organic acid degradation (Fig 5). It can be concluded that strain MGS-2 is tolerant towards low $\mathrm{pH}$ and showed highest 
Table 2 Final culture $\mathrm{pH}$ of strain MGS-2 with $\mathrm{C} \& \mathrm{~N}$ source variations after 48 hours of incubation

\begin{tabular}{ccccc}
\hline \multirow{2}{*}{$\begin{array}{c}\text { Nitrogen } \\
\text { Source }\left(\mathrm{g} \mathrm{L}^{-1}\right)\end{array}$} & 33,1 & $66,2^{2}$ & 99,3 & 132,4 \\
\cline { 2 - 5 } & $5,34^{\mathrm{ef}}$ & $5,2^{\mathrm{bc}}$ & $5,22^{\mathrm{bcd}}$ & $5,32^{\mathrm{e}}$ \\
2 & $5,43^{\mathrm{g}}$ & $5,25^{\mathrm{cd}}$ & $5,18^{\mathrm{b}}$ & $5,22^{\mathrm{bcd}}$ \\
3 & $5,39^{\mathrm{fg}}$ & $5,22^{\mathrm{bcd}}$ & $5,19^{\mathrm{b}}$ & $5,08^{\mathrm{a}}$ \\
4 & $5,26^{\mathrm{d}}$ & $5,34^{\mathrm{ef}}$ & $5,2^{\mathrm{bc}}$ & $5,12^{\mathrm{a}}$ \\
\hline
\end{tabular}

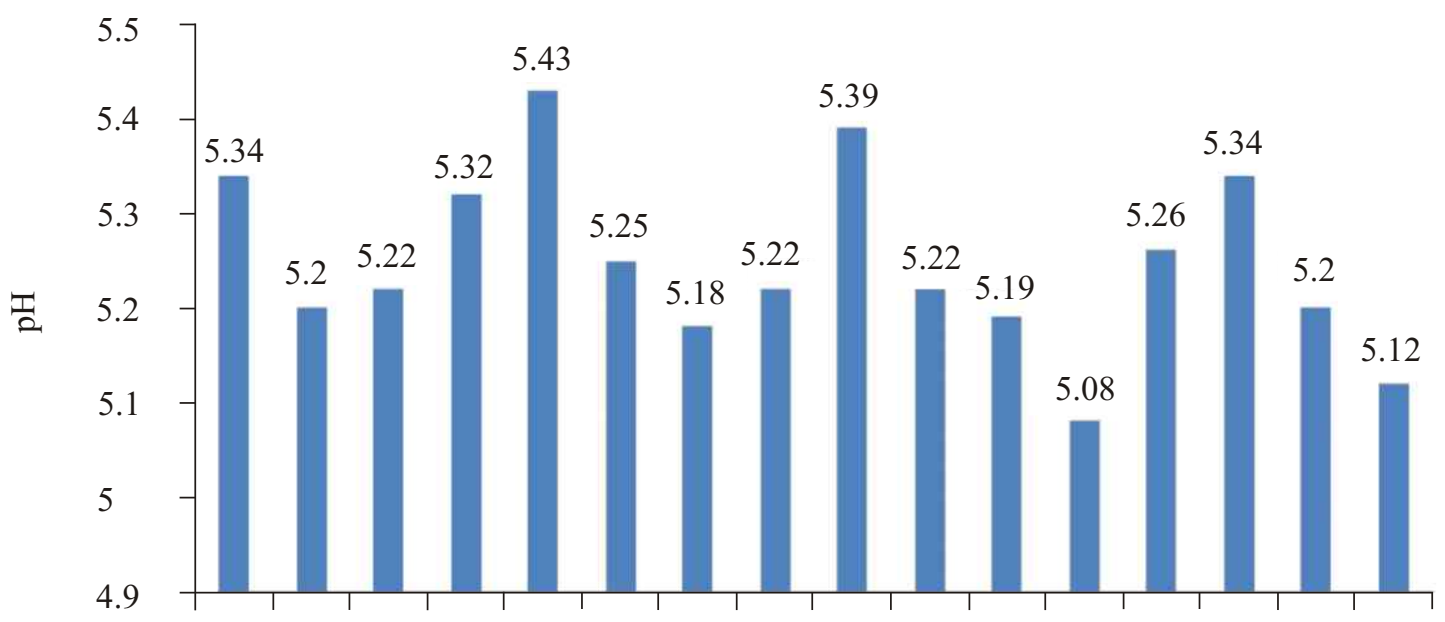

$\begin{array}{llllllllllllllll}\mathrm{C} 1 & \mathrm{C} 2 & \mathrm{C} 3 & \mathrm{C} 4 & \mathrm{C} 1 & \mathrm{C} 2 & \mathrm{C} 3 & \mathrm{C} 4 & \mathrm{C} 1 & \mathrm{C} 2 & \mathrm{C} 3 & \mathrm{C} 4 & \mathrm{C} 1 & \mathrm{C} 2 & \mathrm{C} 3 & \mathrm{C} 4 \\ \mathrm{~N} 1 & \mathrm{~N} 1 & \mathrm{~N} 1 & \mathrm{~N} 1 & \mathrm{~N} 2 & \mathrm{~N} 2 & \mathrm{~N} 2 & \mathrm{~N} 2 & \mathrm{~N} 3 & \mathrm{~N} 3 & \mathrm{~N} 3 & \mathrm{~N} 3 & \mathrm{~N} 4 & \mathrm{~N} 4 & \mathrm{~N} 4 & \mathrm{~N} 4\end{array}$

Carbon and nitrogen source variations

Fig $1 \mathrm{pH}$ value of strain MGS-2 growth media with carbon and nitrogen source variations.

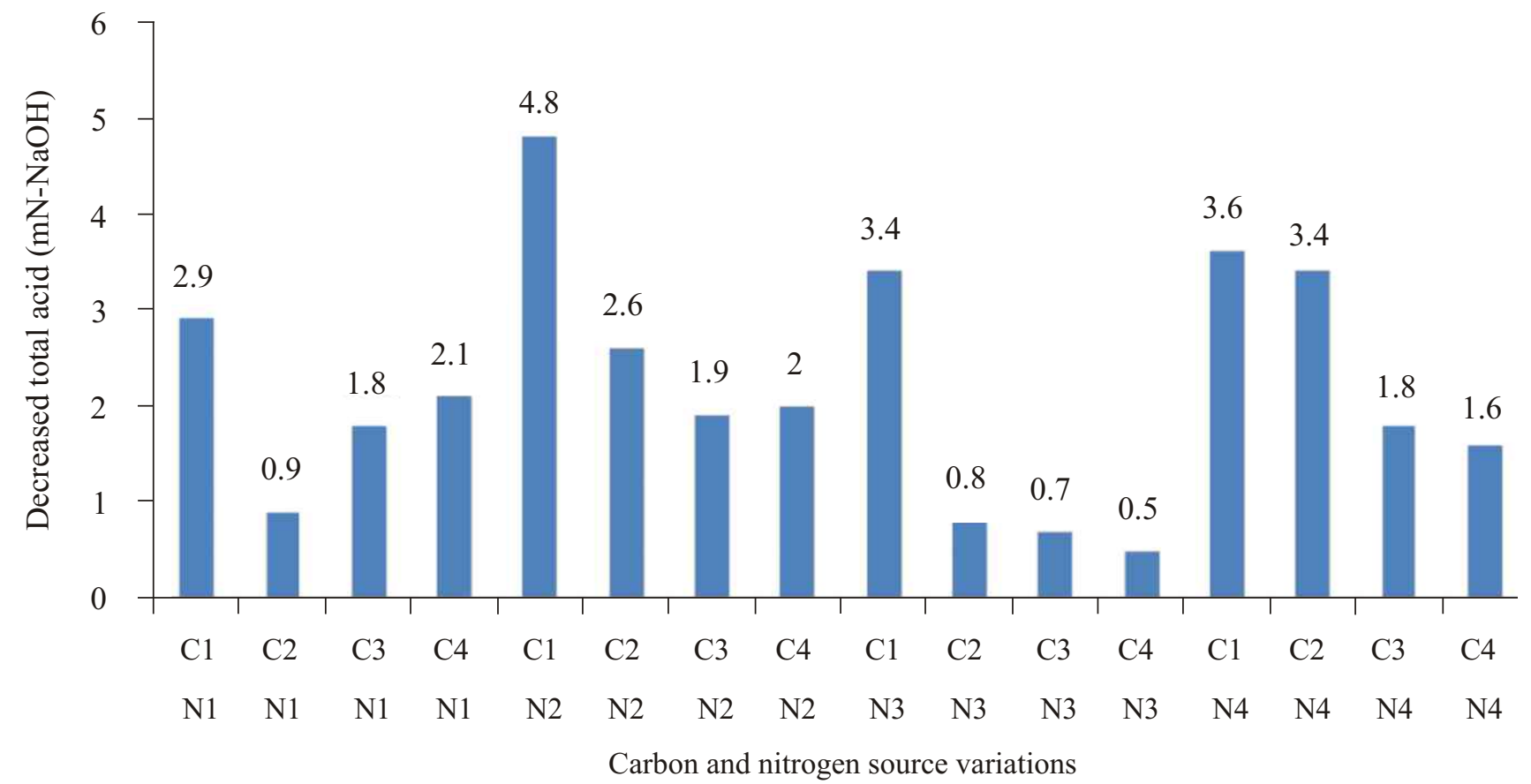

Fig 2 Decreased total acid consumed by strain MGS-2 in growth media with carbon and nitrogen source variations 


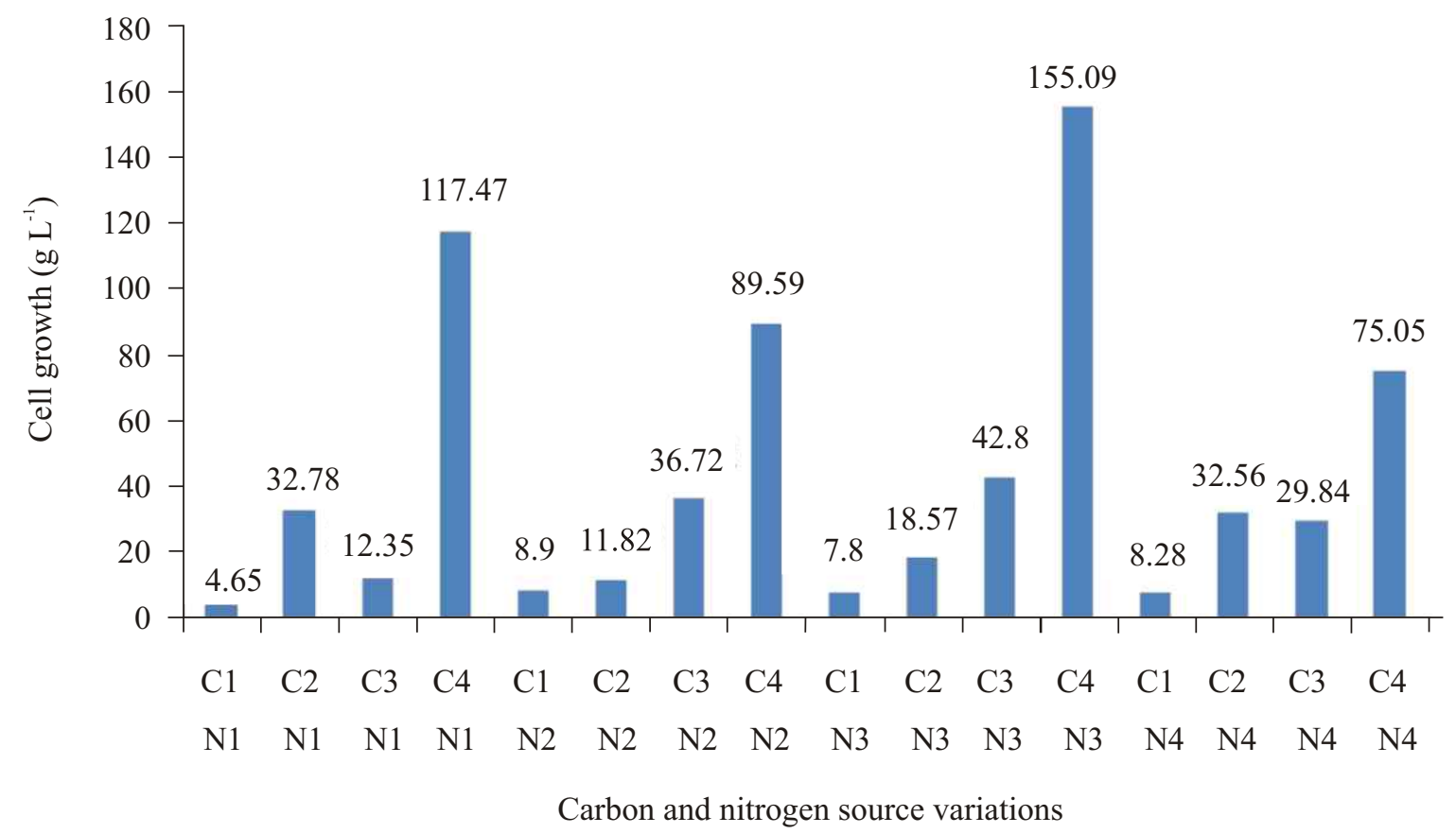

Fig 3 Cell growth of strain MGS-2 in growth media with carbon and nitrogen source variations.

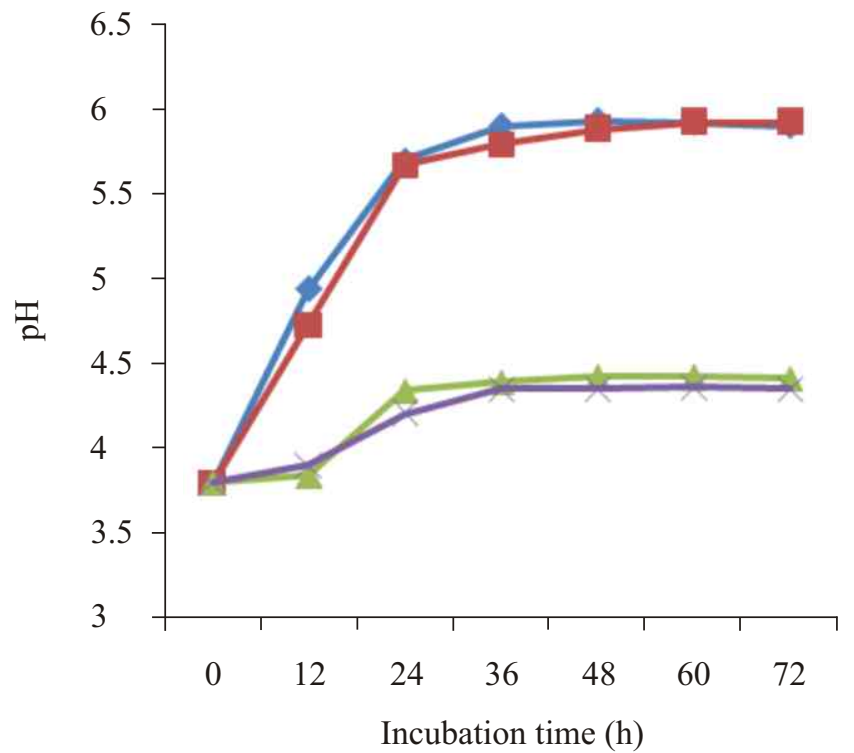

Fig 4 Yeast extract effects on the growth of strain MGS-2. $\multimap$ : carbon and nitrogen optimal, $-\longrightarrow:$ non $\left(\mathrm{NH}_{4}\right)_{2} \mathrm{SO}_{4}, \longrightarrow:$ non yeast, and $\longleftarrow$ : non non $\left(\mathrm{NH}_{4}\right)_{2} \mathrm{SO}_{4}$ and yeast.

degradation activity of organic acid as a sole carbonat pH 3.8.

Growth of MGS-2 in the Optimum Medium. The rise of $\mathrm{pH}$ in the medium until $12 \mathrm{~h}$ incubation showed that strain MGS-2 was not only capable in consuming phenolic acid ( $p$-hydroxybenzoic acid), but also capable to utilize non-phenolic organic acids for their growth (Fig 6 and Fig 8). Non-phenolic organic acids consumption possibly started from the initial growth phase until the maximum growth phase (6-12 h incubation). The increment of culture $\mathrm{pH}$ was also followed by reduction in total acid, started from 6 to 12 $\mathrm{h}$ incubation (Fig 6). During the period of incubation, the cell growth was inclined, and then declined after the $12 \mathrm{~h}$ (Fig 7). Depleting of organic acid in the medium possibly caused lysis in the fungal cells. The $p$ hydroxybenzoic acid was even already consumed during the early growth phase. In addition, the phenolic acid ( $p$-hydroxybenzoic acid) was also possibly already degraded during the early growth phase (6-12 $\mathrm{h}$ incubation), because it was not detected in the medium during that incubation period (Fig 8).

Molecular Identification. The BLAST result of the 28S rDNA sequence of strain MGS2 showed 100\% 


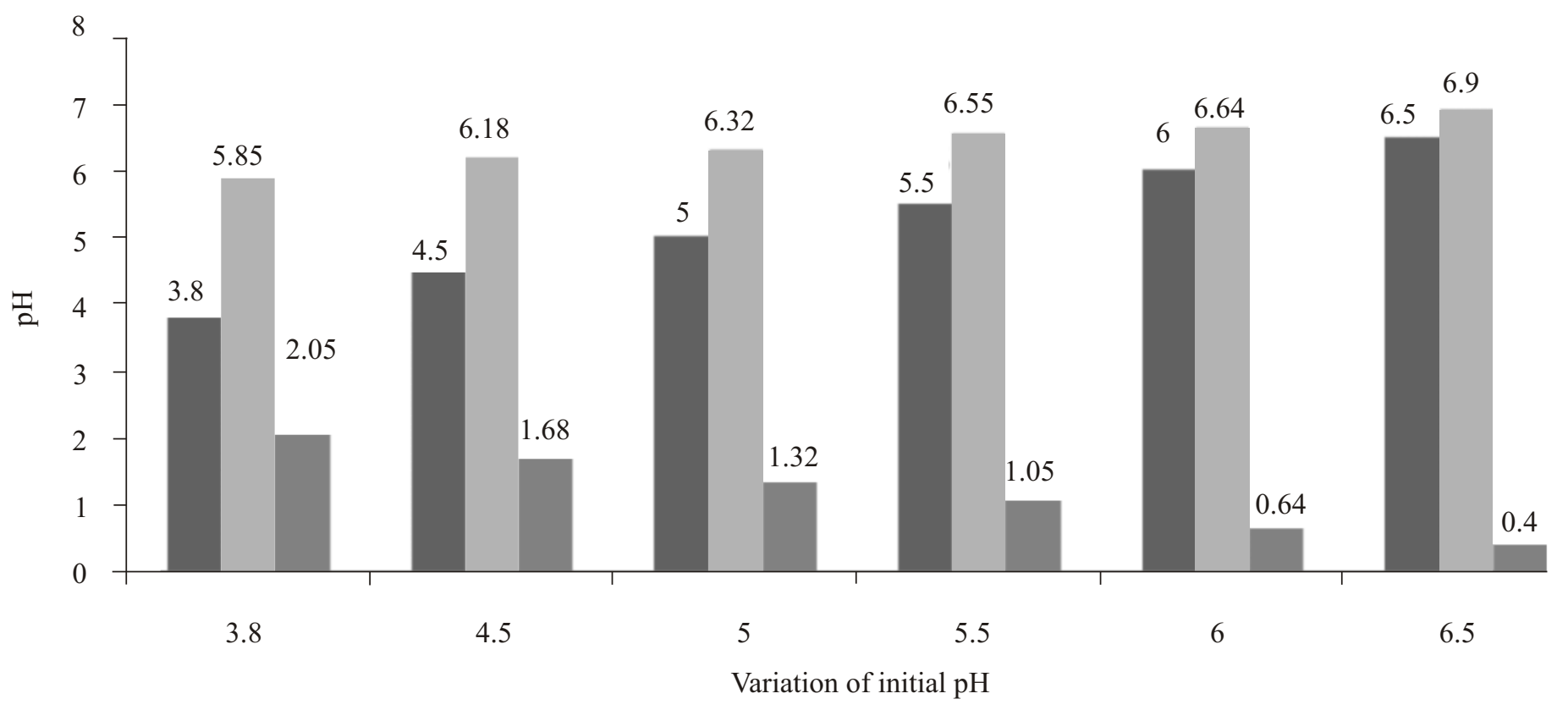

Fig 5 Influences of initial pH on the growth of strain MGS-2. $\square$ : Initiated pH, $\square$ : final pH, and $\square: \Delta \mathrm{pH}$.

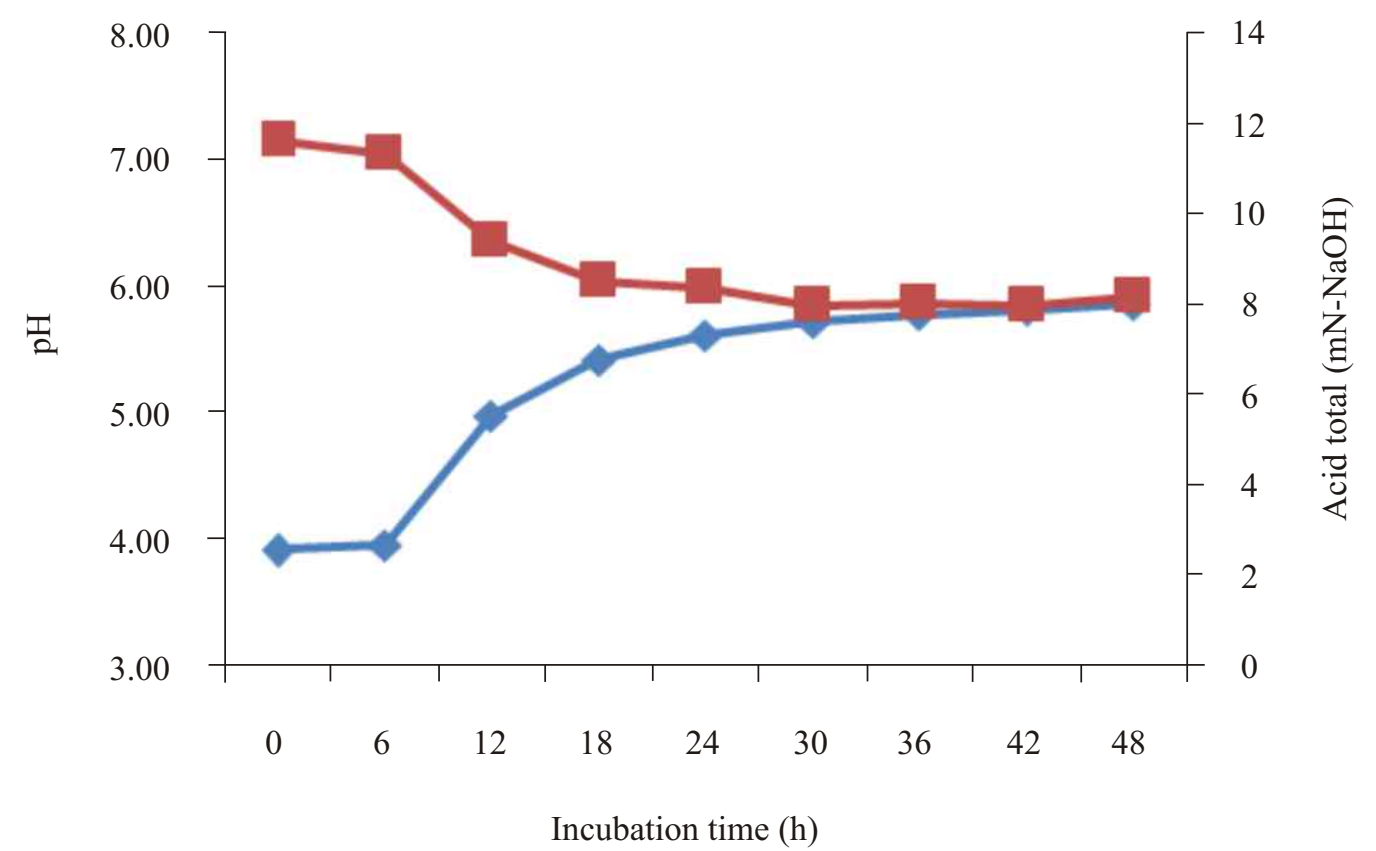

Fig $6 \mathrm{pH}$ and total acid value during the growth of strain MGS-2 in optimum medium for $48 \mathrm{~h} . \smile$ :pH and $\multimap-$ :acid total.

similarity and query coverage to several species of Trichoderma/Hypocrea. The highest similarity is Hypocrea sp. (GU048594.1). The phylogenic tree (Fig 9) indicated that strain MGS-2 showed a close phylogenetic relationship to Hypocrea sp. (Gu048594.

1) Genus Hypocrea is a telemorph state (sexual) of Trichoderma.

\section{DISCUSSION}

A fungus utilizing organic acid extracted from peat soil as a sole carbon source has been isolated and characterized. Carbon and nitrogen are essential nutrition required by microbes for their growth and metabolism. Gao et al. (2007) stated that carbon and nitrogen demand varies in different strains of fungi depending on each strains growth characteristic. Strain MGS-2 can grow optimally in medium containing $2 \mathrm{~g}$ $\mathrm{L}^{-1}$ of ammonium sulphate. The same concentration of ammonium sulphate was also reported capable to increase the growth of Phytophthora capsici (Perveen, 2010). Hypocrea sp. strain MGS-2 was also optimally 


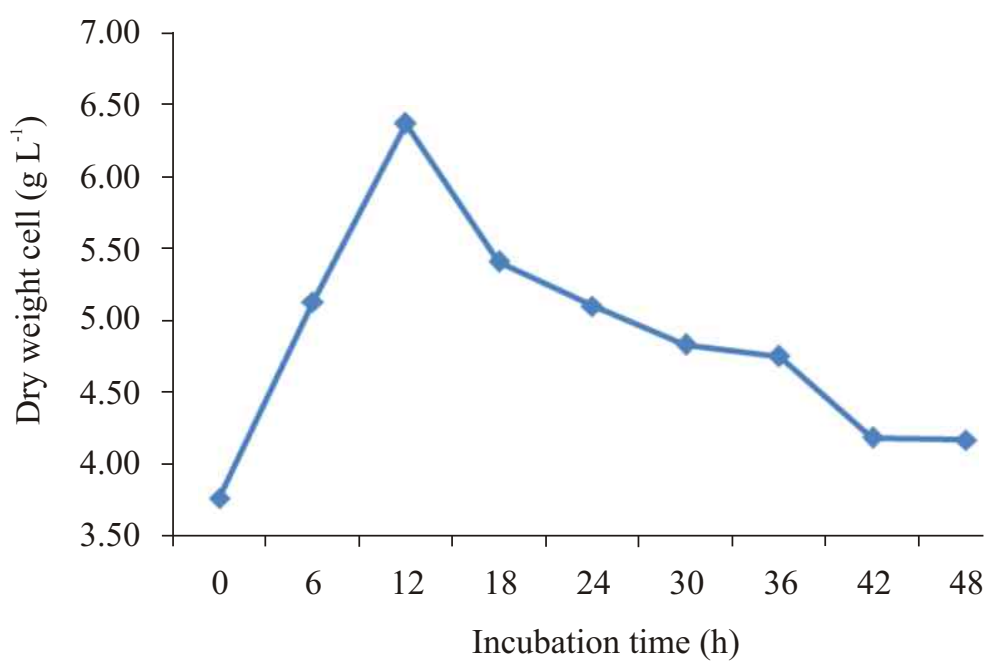

Fig 7 Cell growth of strain MGS-2 in optimum medium during $48 \mathrm{~h}$ incubation.

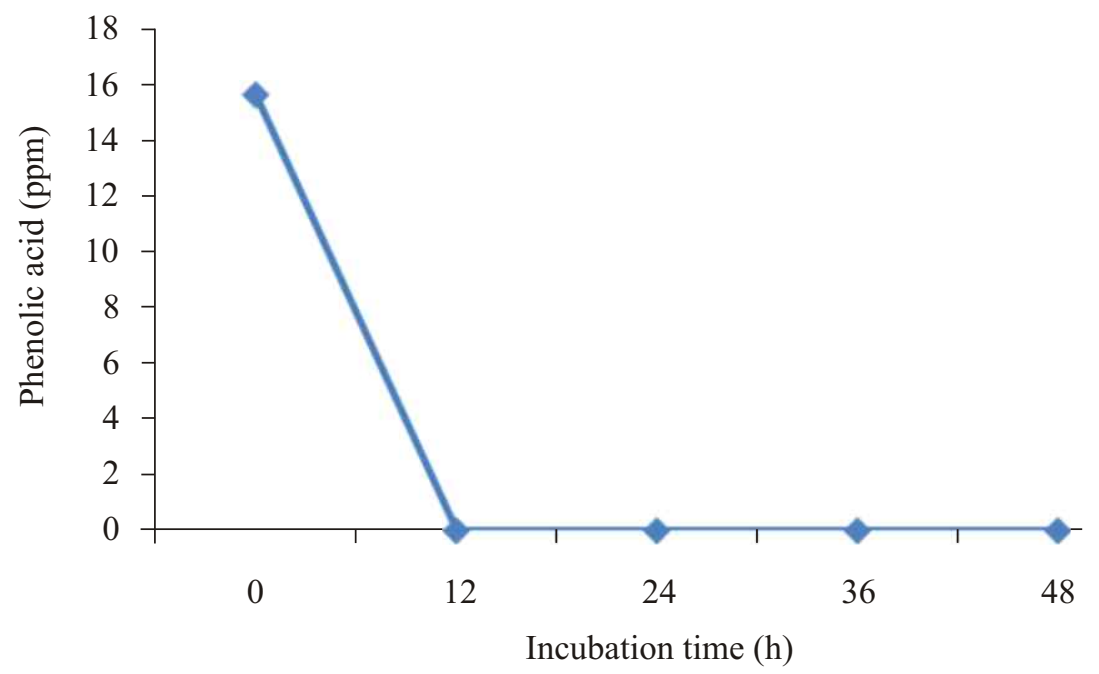

Fig 8 Phenolic acid consumption by strain MGS-2 in optimum medium.

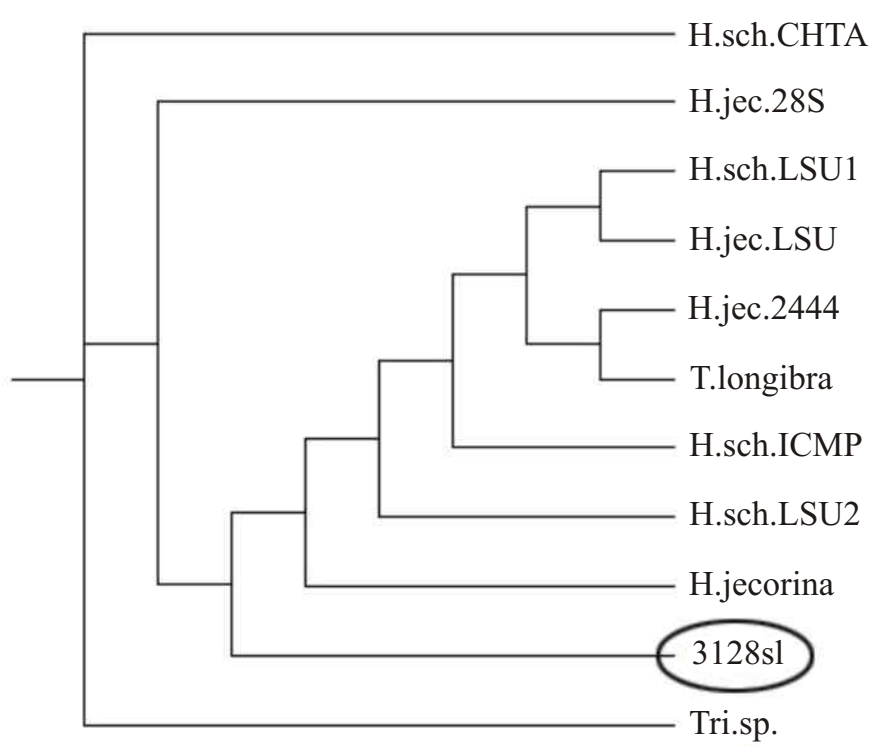

Fig 9 Phylogenetic analysis of strain MGS-2 based on 28s rDNA analysis. The MGS-2 strain is identified as Hyprocrea sp (circled). The other strain are H.sch.CHTA: Hypocrea schweinitzii (GU048594.1), H.jec.28S : Hypocrea jecorina (AF127154.1), H.sch.LSU1: Hypocrea schweinitzii LSU,(AY281095.1), H.jec.LSU: Hypocrea schweinitzii LSU(AY281097.1), H.jec.2444: Hypocrea jecorina 24449 LSU (HM466681.1, T.longibra: Trichoderma longibrachiatum ATCC 18648 LSU (HM466682.1), H.sch.ICMP: Hypocrea schweinitzii ICMP1694 LSU (AY283549.1), H.sch.LSU2: Hypocrea schweinitzii LSU (AF279395.1), H.jecorina: Hypocrea jecorina, Tri.sp.: Trichoderma sp. (KJ372238.1). 
grown at $33.1 \mathrm{mM}-\mathrm{NaOH}$. Several species of microbes have the ability to degrade phenolic acid and utilize it as their carbon source, these include Azotobacter, Streptomyces sannanensis, Schyzophyllum commune, Pycnoporus cinnabarinus, Trametes sp., Paecilomyces variotii (Juarez et al. 2005; Ghosh et al. 2006, 2007; Sachan et al. 2010). The studies on microbial degradation of hydroxybenzoic acids provide a wealth of knowledge on the metabolism of this compound (Chatterjee et al. 1987; Suemori et al. 1995).

During the growth of Hypocrea sp. strain MGS-2, the availability of yeast extract was proven as essential factor. Yeast extract possibly contains vitamins or certain amino acids which are important for the growth of Hypocrea sp. strain MGS-2. Other studies, using Clostridium thermoaceticum grown in mineral medium, showed that only nicotinic acid derived from yeast extract essentially needed in the formation of $\mathrm{NAD}^{+}$during its growth (Koesnandar et al. 1990). The requirement of yeast as a growth factor by Hypocrea sp. is an interesting phenomenon, because fungi usually require a simple medium. It is well known that bacteria require a more complex medium requirements. The ability Hypocrea sp. strain MGS-2 to utilized organic acids as sole carbon sources derived from peat soil, suggested that the increment of culture $\mathrm{pH}$ was due to the deletion of organics acid in the culture.

The ability of Hypocrea sp. to degrade toxic organic acid has never been reported. This phenomenon is advantages because some organic acids derived from lignocellulose in peat soil is toxic to plant to grow (Guenzi and McCalla, 1966). Mendonca et al. (2004) reported that Fusarium flocciferum was able to degrade phenolic acid, while according to Sachan el al. (2010), strain Schizophyllum commune was able to convert coumaric acid into $p$-hydroxybenzoic acid. Streptomyces sannanensis was also reported for its ability to degrade ferulic acid (Ghosh et al. 2007). Among the group of bacteria, Azotobacter chroococcum was able to degrade $p$-hydroxybenzoic acid in 24 hours of incubation (Juarez et al. 2005). Bacillus sp. and Pseudomonas sp. produce $p$ hydroxybenzoic acid hydroxylase which is used in degrading $p$-hydroxybenzoic acid into protocatechuic acid (Karegoudar et al. 2000). Since hydroxybenzoic acid are the most important intermediate compound in the microbial degradative pathways of various aromatic compound (Karegoudar et al. 2000), this is might be the reason that hydroxybenzoic acid was metabolized by Hypocrea sp. strain MGS-2 very fast
(Fig 8), followed by utilization of other organic acids derived from peat soil (Fig 8). Thus capability Hypocrea sp. strain MGS-2 to metabolize organic acid is important to release toxic compound and decreased soil acidity. Previously we reported that a mixture of undefined microbes was able to improve $\mathrm{pH}$ and other chemicals properties of peat soil (Nurani, et al. 2007), suggested that the effectivity of Hypocrea sp. strain MGS-2 to improve peat soil characteristics is required.

The present result showed the ability of Hypocrea sp. MGS-2 to metabolize organic acid derived from peat soil in a defined medium. The application the Hypocrea sp. MGS-2 to eliminate phytotoxic and improve peat soil characteristics as well as increase plant pruduction is under investigation.

\section{ACKNOWLEDGMENT}

We would like to thank Andreas Prof. Dr. Ir. Dwi Santosa, MS. of Institut Pertanian Bogor for his valuable discussion. We like to thank Ahmad Fauzi, Reni Giarni, Ruzka Radwamina, and Farah of the Agency for the Assessment and Application of Technology for their support on technical matters

\section{REFERENCES}

Alexander M. 1977. Introduction to Soil Microbiology. John Willey \& Sons New York

Chatterjee DK, Bourquin AW . 1987. Metabolism of aromatic compounds by Caulobacter crescents. J Bacteriol. 169(5):1993-1996.

Ghosh S, Sachan A, A Mitra. 2006. Formation of vanillic acid from ferulic acid by Paecilomyces variotii MTCC 6581. Curr Sci. 90(6):825-829.

Ghosh S, Sachan A, Sen SK, Mitra A . 2007. Microbial transformation of ferulic acid to vanillic acid by Streptomyces sannanensis MTCC 6637. J Ind Microbiol Biotechnol. 34(2):131-138. doi:10.1007/s10295-006-0177-1.

Guenzi WD, McCalla TM. 1966. Phenolic acids in oats, wheat, sorghum, and corn residues and their phytotoxicity. J Agron. 53(3):303-304. doi:10.2134/agronj1966.0002196200580003001 $7 \mathrm{x}$.

Hartley RD, Whitehead, DC. 1984. Phenolic acids in soil and their influence of plant growth and soil microbial processes. Dalam Vaughan, D. dan R.E. Malcolm. Soil Organic Matter and Biological Activity. Martinus Nijhoff/DR. W. Junk Publisher. Lancaster.

Juarez B, Martinez TMV, Gonzalez LJ. 2005. Growth of Azotobacter chroococcum in chemically defined media containing $p$-hydroxybenzoic hcid 
and protocatechuic acid. Chemosphere. 59(9):1361-1365. doi:10.1016/j.chemosphere.20 04.11.037.

Karegoudar TB, Kim CK. 2000. Microbial degradation of monohydroxybenzoic acids. J Microbiol. 38(2):53-61.

Koesnandar N. Nishio SN. 1990. Stimulation by cysteine on growth of Clostridium thermoaceticum in minimal medium. Appl Microb Biotechnol. 32(6):711-714. doi:10.1007/BF00164746.

Labeda DP. 1990. Isolation of Biotechnological Organisms from Nature. McGraw-Hill Publishing Company. New York.

Li G, Sun MH, Liu XZ, Yong CS. 2007. Effects of carbon concentration and carbon to nitrogen ratio on the growth and sporulation of several biocontrol fungi. Myco Res.111(1):87-92. doi:10.1016/j.mycres.2006.07.019.

Maciak F, H Harms. 1986. The Effect of agricultural utilization on the composition and yield of phenolic acids in low peat soils. Plant and Soil 94(2):171-178. doi:10.1007/BF02374341.

McCarty GW, Bremner JM. 1986. Effects of phenolic compounds on nitrification in soil. Soil Sci Soc Am J. 50(4):920-922. doi:10.2136/sssaj1986.036 15995005000040018x.

Mendonca EA. Martins AMA. 2004. Biodegradation of natural phenolic compounds as single and mixed substrates by Fusarium flocciferum. J Biotechnol. 7(1):30-37.

Mohamed MAN, Sebai TNM, Hartmann A. 2009. Effect of co-enrichment, soybean rhizosphere and $p$-hydroxybenzoic acid, on microbial metabolic diversity and p-HBA degradation. J Agric Biol Sci. 5(4):301-309.
Nurani D, Parmiyatni S, Purwanta H, Angkoso G, Koesnandar. 2007. Increase in $\mathrm{pH}$ of peat soil by microbial treatment. International Symposium and Workshop on Tropical Peatland. Yogyakarta, 27-31 August 2007.

Park HS, Kim GY, Nam BH, Lee SJ, Lee JD. 2002. The Determination of the Partial 28S Ribosomal DNA Sequences and Rapid Detection of Phellinus linteus and Related species. Mycobiology 30(2):82-87. doi:10.4489/MYCO.2002.30.2.082.

Perveen R. 2010. Effect of nitrogen and carbon from different organic supplements on pathogenic potential of Phytophthora capsici, in the collar rot of Chillies. Eur J Sci Res. 43(1):107-112.

Sachan A, Gosh S, Mitra A. 2010. Transforming pcoumaric acid into $p$-hydroxybenzoic acid by the mycelial culture of a White Rot Fungus Schizophyllum commune. Afr J Microbiol Res. 4(4):267-273.

Stevenson FJ. 1994. Humus Chemistry : Genesis, Composition, Reaction. John Wiley \& Son. New York.

Suemori A, Nakajima K, Kurane R, Nakamura Y. 1995. $o-, \quad m$ - and $p$-Hydroxybenzoate degradative pathways in Rhodococcus erythropolis. FEMS Microbiol Lett. 125(1):31-36. doi:10.1111/j.15746968.1995.tb07331.x.

Tadano T, Yonebayashi K, Saito N. 1992. Effect of phenolic acids on the growth and occurrence of sterility in crop plants. Pp: 358-369. In: K. Kyuma, P. Vijarnsorn, and A. Zakaria $(E d s)$. Coastal lowland ecosystems in southern Thailand and Malaysia. Showado-printing Co. Skyoku. Kyoto. 